\title{
Jedinečná procházka labyrintem nářečních slov
}

Stanislava Kloferová - Milena Šipková (eds.):

\section{Život ve slovech, slova v životě. Procházka labyrintem českých nářečí.}

Praha: Nakladatelství Lidové noviny, 2018, 210 s.

ISBN 978-80-7422-657-1.

Pochybovat o tom, že tradiční nářečí zanikají, může už jen málokdo. I dnes však po nich zůstává bohatství slov a slovních obratů. Nesou v sobě odraz dávné historie a vypovídají o tom, jak lidé dříve žili, jak uvažovali, jak pocitovali, prožívali a vůbec vnímali svět okolo sebe.

Jak plyne z citované pasáže recenzované knihy, je jen dobře, že vedle teoretické a badatelské práce, která je základním posláním jazykovědců z Ústavu pro jazyk český AV ČR, v. v. i., nezůstává stranou jejich zájmu vydávání publikací určených široké veřejnosti. V tomto roce 2019 k nim přibyla zajímavá kniha: pracovníci brněnského dialektologického oddělení Ústavu pro jazyk český (pod vedením zkušených lingvistek Stanislavy Kloferové a Mileny Šipkové) ji vydali v Nakladatelství Lidové noviny. Kniha je výsledkem obsáhlého grantového projektu GA ČR Odraz života našich predků v mizejících slovech, zpracovávaného v letech 2016-2018.

Autorský kolektiv tvoří 11 pracovníků, jejichž zkušenost z odborné práce se odráží již ve výběru vykládaných nářečních slov a slovních obratů. Autoři v publikaci využili a zúročili své znalosti, které získali při mnohaleté práci na Českém jazykovém atlasu, rozsáhlém díle české dialektologie, a které nyní dále uplatňují a prohlubují při př́pravě Slovníku nářeči českého jazyka. O dílčích výsledcích tohoto projektu jsme informováni průběžně: v odborných periodikách, na konferencích i v médiích, kde autorský kolektiv představoval výsledky svých bádání odborníkům z celé republiky - dokladem toho jsou položky v bohatém seznamu literatury, který odkazuje $\mathrm{k}$ dalším publikacím a zdrojům z různých tematických oblastí.

Již název knihy, grafické ztvárnění obalu, poutavý text na přebalu (z něhož je převzat úvodní odstavec tohoto př́spěvku) i názvy jednotlivých kapitol dávají tušit, že půjde o téma zajímavé a přitažlivé.

Autorská monografie má 33 kapitol. Stěžejní je úvodní teoretická kapitola, která zdařile motivuje čtenáře, aby četl dále: uvádí ho do problematiky nářečí, zevrubně popisuje a shrnuje jejich vývoj, charakterizuje současný stav užívání nářečních slov a frazémů v češtině. Zabývá se mj. důvody, jak a proč nářeční slova ustupují a zanikají. Obecně je známo, že ústup slov souvisí s vývojem společnosti, se změnami, jimiž společnost prochází. Studie připomíná dvě hlavní příčiny zániku slov, a to že 1. slova mizí spolu s reáliemi - s objekty, věcmi, jevy - a dále že 2. slova mizí též s mizející potřebou určité objekty, věci nebo jevy pojmenovat, byt existují, ale v současnosti jejich přesné pojmenování již uživatelé nepotřebují. To se týká např. jevů souvisejících s počasím: málokdo dnes umí diferencovat déšt různé intenzity (např. ced'ák, chlejsták, chrsták, spršák, špráchanec) nebo různé druhy padání kapek z mračen (cáká, chlístá, chršče, kape, romejší). 
Jednotlivé kapitoly nejsou strukturovány stejně, každý autor má svůj specifický autorský styl, každé téma vyžaduje jiný př́stup i způsob zpracování. Delší propracované a tematicky ucelené studie jsou střídány kratšími př́spěvky, věnovanými jednotlivým slovům či frazémům. Výklady jsou formulovány př́stupnou formou, jasně a přehledně, a s ohledem na nepoučeného čtenáře jsou užité odborné termíny vysvětlovány. Čtivá forma populárně-naučného výkladu vyzývá $\mathrm{k}$ zamyšlení laického i poučeného čtenáře a ukazuje mnohé zajímavé souvislosti. Ilustrativnost doplňuje značný počet př́kladů, vždy regionálně zařazených do př́slušné nářeční oblasti. Ty autoři čerpali z obsáhlého Archivu lidového jazyka, bohaté pokladnice nářečí, uložené v dialektologickém oddělení Ústavu pro jazyk český AV ČR a zahrnující přes 1,5 milionu nářečních dokladů od poslední třetiny 19. stol. až do současnosti.

Každá kapitola podává zprávu nejen o životě nářečních slov, ale i o tradičním způsobu života našich předků: vedle dialektologických informací přináší poznatky z dalších disciplín, jako jsou onomastika, etymologie, etnologie a historie ad. Např. v kapitole Chléb náš vezdejší se čtenář dovídá mnoho zajímavého jak o výrazech spojených s chlebem (např. zákalec, slípka, brousek ad.), tak o tradičním pečení chleba. Následují kapitoly věnované kvasnicím (Kvasnice, droždí a hýbadla), knedlíkům a šiškám či objasňující významový rozdíl mezi slovy sodovka a limonáda. Pozornost je věnována rovněž tradičním řemeslům a již zaniklým činnostem, zaujme např. bohatství pojmenování podomních obchodníkủ, kteří se v minulosti pohybovali na našem území. Mnohá tato pojmenování již ztratila pro dnešního uživatele srozumitelnost a svědectví o jejich existenci dnes dokládají jen některé frazeologické obraty; čtenář se např. dozví, proč se říká chod'íjag hadrňík, pochodil jag hupkař, huba i jede jak šlejfiřce ad. Seznámí se rovněž s nářečními slovy a frazeologickými obraty spojenými s nemocemi a s lidovým léčitelstvím (např. v kapitolách Lidové léčitelky, bohyně; O chřadnutí aneb dyž je clověk je chytlý na plúca a karhá), s lidovou magií (a s čarodějnicemi), s jídlem i s tradičními kuchařskými postupy, s dětskými hrami (Slepá bábo, kam tě vedu?), s dříve užívanými mírami (O provazcích a odměrkách) a s historií některých jmen. Nezř́́dka museli autoři podniknout téměř detektivní pátrání, aby se dobrali k prezentovaným poznatkům a závěrům. To dokládá např. kapitola poodhalující tajemství pomístních jmen, která přináší překvapivé informace o původu na první pohled průhledných jmen jako Fialka, Balík nebo Hádka.

Specifickou součástí nářeční slovní zásoby jsou slova přejatá z jiných jazyků, zejména $\mathrm{z}$ němčiny (Šmak a košt ad.), a také výrazy spojené s karpatskou salašnickou kolonizací (Brynza, domikát, č́r a dalš́ salašnické výrazy). Pozoruhodná jsou citově zabarvená slova označující nositele nápadných (převážně negativních) lidských vlastností. Co asi vypovídá o české národní povaze sdělení, že v Archivu lidového jazyka se nachází 250 dokladů nářečních pojmenování pro lakomce (např. mamoňák, záchtivec, hamouzník) a ještě více pro alkoholiky (např. dopilkuba, močihuba, bumbálek)? K tomuto tematickému okruhu lze přiřadit též jména pachatelů nekalé činnosti, která zobecněla jako hodnotící pojmenování (Lecián, Šimák a ti druzí). Leckterého čtenáře patrně překvapí významová pestrost slovních spojení s př́ídavnými jmény boží a čistý v našich nářečích. Poslední, krátká kapitola O kotovicích a Kotovicích pak přichází s vtipnou pointou, objasňující původ nářečního slova, které může způsobit nedorozumění v oblasti Čech, protože tam není známé. 
A to není zdaleka vše - obsáhnout zde všechna témata, která knížka přináší, nelze. Čtenář ještě zjistí, co znamená řada dalších, dříve běžně používaných slov, která dnes již málokdo zná, jako jsou např. čumbrky, hladolet, domikát, kuřírit', krátký sušky, zouvák a mnoho dalších.

Není pochyb o tom, že procházka labyrintem nářečních slov s nejpovolanějšími průvodci potěší nejen odborníky, ale zaujme i laiky, zájemce z řad široké veřejnosti, učitele, studenty, všechny, které zajímá čeština a bohatství jejích nářečí, v nichž se odráží tradiční způsob života našich předků a která spojují jejich zaniklý svět se současností.

\section{Jarmila Vojtová}

Department of Czech Language

Faculty of Arts, Masaryk University

A. Nováka 1, 602 oo Brno

Czech Republic

vojtovaj@phil.muni.cz 